\title{
Reproduksi Sehat, Remaja Sehat Di Posyandu Remaja Pashmina
}

\author{
Miftachul Jannah, Pedvin Ratna Meikawati, Swasti Artanti \\ Email : miftachuljannsh88@gmail.com \\ DIII Kebidanan, Akademi Kebidanan Harapan Ibu Pekalongan, Indonesia \\ Jl. Sriwiaya No. 7 Pekalongan \\ HP. 085641541222
}

\begin{abstract}
Abstrak
Remaja adalah orang yang berusia 12 hingga 24 tahun. Masa remaja merupakan peralihan dari kanak-kanak menjadi dewasa. Artinya, proses pengenalan dan pengetahuan kesehatan reproduksi sebenarnya sudah dimulai pada masa ini. Secara sederhana, reproduksi berasal dari kata "re" yang berarti kembali dan "produksi" yang artinya membuat atau menghasilkan. Kesehatan reproduksi, sebagai bagian dari kesehatan secara umum dengan demikian juga merupakan hak asasi setiap orang baik laki-laki maupun perempuan. Hak asasi perempuan diatur dalam Undang-Undang Nomor 39 tahun 1999 tentang HAM Pasal 3 ayat (3) menyebutkan bahwa setiap orang berhak atas perlindungan hak asasi manusia dan kebebasan manusia tanpa diskriminasi. Kesehatan reproduksi menurut Undang-Undang Nomor 36 Tahun 2009 adalah keadaan secara fisik, mental dan sosial secara utuh, tidak semata-mata bebas dari penyakit atau kecacatan yang berkaitan dengan sistem, fungsi dan proses reproduksi pada laki-laki dan perempuan. Tujuan pengabdian masyarakat ini adalah memberikan penyuluhan kesehatan reproduksi tentang reproduksi sehat, remaja sehat khususnya tentang anemia pada remaja, kesehatan reproduksi dan seks bebas pada remaja. Metode penyuluhan kesehatan reproduksi yang dilakukan yaitu (1) Sosialisasi dan perijinan, (2) Melakukan Penyuluhan kesehatan reproduksi, (3) Evaluasi hasil kegiatan penyuluhan kesehatan reproduksi dengan cara pre dan post test. Hasil kegiatan penyuluhan kesehatan reproduksi menunjukkan antuasiasme yang tinggi ditunjukkan respon peserta yang sangat baik dalam menerima materi mengenai reproduksi sehat, remaja sehat serta kemauan peserta untuk bertanya. Antusiasme peserta tersebut diharapkan dapat meningkatkan pemahaman anak perempauan dan laki-laki tentang pentingnya reproduksi sehat, remaja sehat.
\end{abstract}

Kata kunci: kesehatan reproduksi remaja; posyandu remaja.

\begin{abstract}
Adolescents are people aged 12 to 24 years. Adolescence is a transition from childhood to adulthood. This means that the process of introduction and knowledge of reproductive health has actually started at this time. In simple terms, reproduction comes from the word "re" which means to return and "production" which means to make or produce. Reproductive health, as part of general health, is thus also a human right of every person, both men and women. Women's human rights are regulated in Law Number 39 of 1999 concerning Human Rights Article 3 paragraph (3) which states that everyone has the right to the protection of human rights and human freedoms without discrimination. Reproductive health according to Law Number 36 Year 2009 is a complete physical, mental and social condition, not merely free from disease or disability related to the reproductive system, function and process in men and women. The purpose of this community service is to provide reproductive health education about healthy reproduction, healthy adolescents, especially about anemia in adolescents, reproductive health and free sex in adolescents. Methods of reproductive health counseling carried out are (1) Socialization and licensing, (2) Conducting reproductive health counseling, (3) Evaluation of the results of reproductive health counseling activities by means of pre and post tests. The results of the reproductive health counseling activity showed high enthusiasm, indicated by the very good response of participants in receiving material on healthy reproduction, healthy adolescents and the willingness of participants to ask questions. The enthusiasm of the participants is expected to increase the understanding of girls and boys about the importance of healthy reproduction, healthy adolescents.
\end{abstract}

Keywords: adolescent reproductive health; youth posyandu. 


\section{Pendahuluan}

Menurut Organisasi Kesehatan Dunia (WHO), remaja adalah orang yang berusia 12 hingga 24 tahun. Masa remaja merupakan peralihan dari kanak-kanak menjadi dewasa. Artinya, proses pengenalan dan pengetahuan kesehatan reproduksi sebenarnya sudah dimulai pada masa ini. Secara sederhana, reproduksi berasal dari kata "re" yang berarti kembali dan "produksi" yang artinya membuat atau menghasilkan.

Kesehatan reproduksi, sebagai bagian dari kesehatan secara umum dengan demikian juga merupakan hak asasi setiap orang baik laki-laki maupun perempuan. Hak asasi perempuan diatur dalam UndangUndang Nomor 39 tahun 1999 tentang HAM Pasal 3 ayat (3) menyebutkan bahwa setiap orang berhak atas perlindungan hak asasi manusia dan kebebasan manusia tanpa diskriminasi ${ }^{(1)}$.

Kesehatan reproduksi menurut Undang-Undang Nomor 36 Tahun 2009 adalah keadaan secara fisik, mental dan sosial secara utuh, tidak semata-mata bebas dari penyakit atau kecacatan yang berkaitan dengan sistem, fungsi dan proses reproduksi pada laki-laki dan perempuan ${ }^{(2)}$.

Reproduksi bisa diartikan sebagai proses kehidupan manusia dalam menghasilkan kembali keturunan. Karena definisi yang terlalu umum tersebut, seringnya reproduksi hanya dianggap sebatas masalah seksual atau hubungan intim. Alhasil, banyak orang tua yang merasa tidak nyaman untuk membicarakan masalah tersebut pada remaja. Padahal, kesehatan reproduksi, terutama pada remaja merupakan kondisi sehat yang meliputi sistem, fungsi, dan proses reproduksi.
Kurangnya edukasi terhadap hal yang berkaitan dengan reproduksi nyatanya bisa memicu terjadinya hal-hal yang tak diinginkan. Salah satu hal yang sering terjadi karena kurangnya sosialiasi dan edukasi adalah penyakit seksual menular, kehamilan di usia muda, hingga aborsi yang berakibat pada hilangnya nyawa remaja.

Pada dasarnya, remaja perlu memiliki pengetahuan seputar kesehatan reproduksi. Tak hanya untuk menjaga kesehatan dan fungsi organ tersebut, informasi yang benar terhadap pembahasan ini juga bisa menghindari remaja melakukan hal-hal yang tidak diinginkan.

Memiliki pengetahuan yang tepat terhadap proses reproduksi, serta cara menjaga kesehatannya, diharapkan mampu membuat remaja lebih bertanggung jawab. Terutama mengenai proses reproduksi, dan dapat berpikir ulang sebelum melakukan hal yang dapat merugikan.

Pengetahuan seputar masalah reproduksi tidak hanya wajib bagi remaja putri saja. Sebab, anak lakilaki juga harus mengetahui serta mengerti cara hidup dengan reproduksi yang sehat. Pergaulan yang salah juga pada akhirnya bisa memberi dampak merugikan pada remaja laki-laki pula.

Berdasarkan latar belakang di atas maka penulis tertarik untuk melasanakan pengabdian kepada masyarakat yang berjudul "Reproduksi Sehat, Remaja Sehat" Di Posyandu Remaja Pashmina Kelurahan Jenggot Kota Pekalongan", maka perlu diadakannya kegiatan tentang reproduksi remaja sehat dimana anak-anak remaja dapat berdiskusi, tukar pendapat, tukar pengalaman 
tentang kesehatan reproduksi remaja yang dibimbing oleh petugas kesehatan dan petugas kesehatan lainnya dengan cara memberikan materi tentang kesehatan remaja. Dengan adanya posyandu pashmina yang dibimbing oleh petugas kesehatan lewat bidan desanya dan petugas kesehatan lainnya dapat memberikan penyuluhan reproduksi sehat, remaja sehat sehingga dapat meningkatkan pengetahuan remaja tentang reproduksi sehat. Agar kegiatan ini lebih menarik, maka munculah nama kegiatan "Reproduksi Sehat, Remaja Sehat" agar masyarakat remaja lebih tertarik dan memberikan perhatian khusus terhadap kegiatan ini.

Kegiatan pengabdian masyarakat ini bertujuan untuk meningkatkan pengetahuan, sikap dan praktik remaja tentang reproduksi sehat dan remaja sehat.

\section{Metode}

Pengabdian kepada masyarakat yang dilaksanakan di Posyandu Pashmina Kelurahan Jenggot Kota Pekalongan dilakukan beberapa kegiatan dengan cara memberikan penyuluhan kesehatan reproduksi remaja.

Kegiatan pengabdian kepada masyarakat ini dilakukan oleh Dosen sebagai pengusul dan dibantu oleh mahasiswa. Mahasiswa membantu dalam jalannya kegiatan sebagai operator, narasumber kedua serta pencatatan lembar observasi pemeriksaan. Kegiatan dilakukan disalah satu ruangan tertutup yang memadai sarana dan prasarana yaitu penggunaan laptop dan LCD untuk pemaparan materi. Kegiatan ini juga bekerjasama dengan tenaga kesehatan lainnya yaitu Bidan Desa
Puskesmas Jenggot Kota

Pekalongan.

Pelaksanaan

kegiatan pengabdian kepada masyarakat dilakukan dengan 3 tahapan yaitu: Tahap pertama yaitu persiapan kegiatan dengan cara 1) Menentukan prioritas masalah berdasarkan data, 2) Mempersiapkan peralatan yang dibutuhkan saat melakukan kegiatan dan 3) Menentukan waktu pelaksanaan dan lamanya kegiatan bersama tim kegiatan pengabdian kepada masyarakat.

Tahap kedua yaitu pelaksanaan kegiatan. Kegiatan sudah dilaksanakan di Posyandu Pashmina Kelurahan Jenggot Kota Pekalongan, hari Jum'at, 29 Januari 2021 pada jam: $09.00 \mathrm{~s} / \mathrm{d}$ selesai. Pelaksanaan dilakukan oleh Dosen dan melibatkab mahasiswa Akademi Kebidanan Harapan Ibu Pekalongan.

Tahap ketiga yaitu pelaksanaan kegiatan yang terdiri dari 2 langkah yaitu: Petama kegiatan, kegiatan sebelum kegiatan dimulai dilakukan terlebih dahulu pre test dan setelah dilaksanakan kegiatan pun diberikan post test. Kegiatan pendahuluan yaitu perkenalan dan penjelasan tentang pelaksanaan kegiatan inti yaitu penyampaian materi yang akan diberikan sejumlah 3 materi dan tanya jawab. Langkah kedua yaitu langkah metode dengan cara metode ceramah dan tanya jawab.

\section{Hasil dan Pembahasan}

Puskesmas jenggot hanya memiliki satu wilayah kerja yaitu kelurahan Jenggot, dengan luas wilayah $123.500 \mathrm{KM} 2$. Kelurahan Jenggot merupakan salah satu kecamatan pekalongan selatan kota pekalongan Jawa Tengah. Secara geografis kelurahan jenggot ini 
disebelah selatan berbatasan dengan desa simbang wetan, sebelah barat berbatasan dengan desa Buaran, sebelah utara berbatasan dengan desa Kradenan dan sebelah timur berbatasan dengan desa Kuripan Lor dan Kuripan Kidul. Mayoritas mata pencahariaan penduduk Jenggot bergerak di sektor perbatikan, baik sebagai buruh batik, pedagang batik distributor batik maupun produsen batik.

Kegiatan pengabdian masyarakat penyuluhan kesehatan reproduksi pada anak sekolah tentang "Anemia pada remaja, kesehatan reproduksi remaja dan seks bebas pada remaja di Posyandu Pashmina kelurahan jenggot kota pekalongan" diawali dengan survey tempat pengabdian kepada masyarakat dan lembar observasi (pre dan post test) yang akan dipakai pada saat pengabdian dilaksanakan.

Pengabdian kepada masyarakat ini dilaksanakan sesuai dengan kebutuhan yang ada di lingkungan sekolah. Kurangnya kesadaran dan pengetahuan tentang pentingnya kesehatan reproduksi pada remaja untuk mencegah terjadinya masalah yang sering dihadapi oleh anak sekolah.

Pengabdian kepada masyarakat ini dilaksanakan dalam rangka penyuluhan kesehatan terutama kesehatan reproduksi pada masa remaja yaitu dengan memberikan penyuluhan tentang anemia pada remaja, kesehatan reproduksi remaja dan seks bebas pada remaja yang dilakukan di Posyandu Remaja Pashmina Kelurahan Jenggot Kota Pekalongan.

Pelaksana kegiatan pengabdian kepada masyarakat ini dilakukan untuk meningkatkan pengetahuan dan pemahaman tentang penyuluhan kesehatan remaja pada anak sekolah. Pelaksanaan dalam kegiatan ini berupa persiapan kuesioner yang akan digunakan untuk pre -tes dan post test kegiatan ini. Kegiatan ini bertujuan untuk memberikan edukasi kepada anak sekolah tentang reproduksi sehat, remaja sehat sehingga dapat meningkatkan pengetahuan kesehatan reproduksi remaja khususnya tentang anemia pada remaja, kesehatan reproduksi remaja dan seks bebas pada remaja.

Dalam kegiatan pengabdian kepada masyarakat ini di ikuti oleh 37 anak sekolah dalam rentang umur 10-16 tahun. Sebelum kegiatan dilaksanakan, dilakukan tanya jawab untuk mengetahui seberapa besar pengetahuan mereka tentang kesehatan reproduksi pada masa anak sekolah. Pertanyaan berupa pilihan ganda sebanyak 15 soal mengenai anemia pada remaja, kesehatan reproduksi dan seks bebas pada remaja. 
Tabel 3.1 Hasil pre test dan post test

\begin{tabular}{|c|c|c|}
\hline \multirow{2}{*}{ Responden } & \multicolumn{2}{|c|}{ Nilai } \\
\hline & Pre Test & Post Test \\
\hline 1 & 10 & 14 \\
\hline 2 & 6 & 15 \\
\hline 3 & 9 & 15 \\
\hline 4 & 8 & 14 \\
\hline 5 & 9 & 15 \\
\hline 6 & 6 & 15 \\
\hline 7 & 6 & 15 \\
\hline 8 & 7 & 15 \\
\hline 9 & 8 & 15 \\
\hline 10 & 10 & 15 \\
\hline 11 & 11 & 15 \\
\hline 12 & 10 & 15 \\
\hline 13 & 10 & 15 \\
\hline 14 & 9 & 15 \\
\hline 15 & 8 & 15 \\
\hline 16 & 10 & 15 \\
\hline 17 & 10 & 14 \\
\hline 18 & 10 & 14 \\
\hline 19 & 6 & 15 \\
\hline 20 & 6 & 15 \\
\hline 21 & 7 & 13 \\
\hline 22 & 10 & 15 \\
\hline 23 & 9 & 15 \\
\hline 24 & 12 & 14 \\
\hline 25 & 8 & 14 \\
\hline 26 & 10 & 14 \\
\hline 27 & 14 & 15 \\
\hline 28 & 9 & 15 \\
\hline 29 & 9 & 15 \\
\hline 30 & 4 & 15 \\
\hline 31 & 6 & 15 \\
\hline 32 & 7 & 15 \\
\hline 33 & 5 & 15 \\
\hline 34 & 9 & 12 \\
\hline 35 & 5 & 14 \\
\hline 36 & 6 & 14 \\
\hline 37 & 10 & 15 \\
\hline
\end{tabular}

Hasil Tanya jawab yang dilakukan oleh narasumber, dari 37 peserta diketahui 10 peserta remaja putri telah mengalami menstruasi mengatakan bahwa saat menstruasi mengalami cepat lelah dan sulit berkonsentrasi. Anemia menyebabkan darah tidak cukup mengikat dan mengangkut oksigen dari paru-paru ke seluruh tubuh. Bila oksigen yang diperlukan tidak cukup, maka akan berakibat pada sulitnya berkonsentrasi, sehingga prestasi belajar menurun, daya tahan fisik rendah sehingga mudah lelah, aktivitas fisik menurun, mudah sakit karena daya tahan tubuh rendah, akibatnya jarang masuk sekolah ${ }^{(3)}$.

Sebagian besar remaja putri di lingkungan posyandu Pashmina masih kurang paham dalam menjaga konsumsi makanan untuk mencegah anemia, terlihat dari masih banyak yang masih suka mengkonsumsi makanan cepat saji dan sering menjalankan diet karena terpengaruh oleh temannya. Remaja putri pada umumnya memiliki karakteristik kebiasaan makan tidak sehat. Antara lain kebiasaan tidak makan pagi malas minum air puih, diet tidak sehat karena ingin langsing (mengabaikan sumber protein, karbohidrat, vitamin dan mineral), kebiasaan ngemil makanan rendah gizi dan makan makanan siap saji. Sehingga remaja tidak mampu memenuhi keanekaragaman zat makanan yang dibutuhkan oleh tubuhnya untuk proses sintesis pembentukan Hemoglobin ( $\mathrm{Hb}$ ). Bila hal ini terjadi dalam jangka waktu yang lama akan menyebabkan kadar HB terus berkurang dan menimbulkan anemia ${ }^{(4)}$.

Masa remaja merupakan salah satu periode dari perkembangan manusia. Masa ini merupakan masa perubahan atau masa peralihan dari kanak-kanak ke masa dewasa yang meliputi perubahan perubahan biologis, perubahan psikologis dan perubahan sosial. Di sebagian besar masyarakat dan budaya, masa 
remaja pada umumnya dimulai pada usia 10-13 tahun dan berakhir pada usia 18-22 tahun ${ }^{(5)}$.

Pada fase pubertas terjadi perubahan fisik sehingga pada akhirnya seorang anak akan memiliki kemampuan bereproduksi. Terdapat lima perubahan khusus yang terjadi pada pubertas, yaitu, pertambahan tinggi badan yang cepat, perkembangan sekunder, perkembangan organ-organ reproduksi, perubahan komposisi tubuh serta perubahan sistem sirkulasi dan sistem respirasi yang berhubungan dengan kekuatan dan stamina tubuh ${ }^{(6)}$.

Tanda awal pubertas adalah meningkatnya volume testis pada anak laki-laki dan timbulnya penonjolan pertama areola dan papilla payudara pada perempuan. Pertumbuhan rambut aksila dan rambut pubis tidak merupakan pertanda pubertas yang baik karena keadaan ini lebih bayak dipengaruhi oleh hormone ${ }^{(7)}$.

Seks bebas merupakan kebiasaan melakukan seksual secara bebas dilakukan oleh laki-laki dan perempuan yang menentang atau merasa enggan jika diri mereka terikat dalam suatu pernikahan yang suci. Sedangkan menurut Desmita (2005) seks bebas adalah segala cara mengekspresikan dan melepaskan dorongan seksual yang berasal dari kematangan organ seksual, seperti berkencan intim, bercumbu, sampai melakukan kontak seksual tetapi perilaku tersebut dinilai tidak sesuai dengan norma karena remaja belum memiliki pengalaman tentang seksual. Tujuan dari seks bebas sendiri untuk memperoleh kepuasaan dan relaksasi dalam kehidupan (bagi manusia) ${ }^{(8)}$.

Perilaku seksual merupakan sebuah pelanggaran, menurut Kitab Undang-Undang Hukum Pidana disebut dengan kejahatan. Namun dalam praktik kehidupan sehari-hari sering terjadi perilaku seksual yang disebut dengan pelecehan seksual, seperti kekerasaan seksual, pelecehan seksual, pemaksaan perkawinan, pemaksaan aborsi ${ }^{(8)}$. Kitab Undang-Undang Hukum Acara Pidana (KUHAP).

Dalam Undang-Undang Dasar Tahun 1945 menyebutkan tentang kebebasan anak yang ditinjau dalam BAB 10 A tentang hak asasi manusia yaitu pada pasal $28 \mathrm{~B}$ ayat 2, bahwa setiap anak berhak atas kelangsungan hidup, tumbuh dan berkembang serta berhak atas perlindungan dari kekerasan dan deskriminasi. Pada pasal KUH Perdata menyebutkan bahwa kedewasaan seorang anak yang dewasa batas usianya 21 tahun karena disusia tersebut seorang anak telah mampu membedakan mana yang baik dan mana yang buruk sesuai dengan jati diri yang dimilikinya sehingga tidak mampu terpengaruh oleh hal-hal negatif yang ada disekililingnya (9). Undang-Undang Dasar 1945 Dasar Negara Republik Indonesia 1945 Pasal 28 B ayat 2.

Banyak faktor yang mempengaruhi perilaku seksual bebas, anatara lain hubungan antara orang tua dengan remaja yang kurang dekat, pergaulan teman sebaya tanpa batas, regligius dan paparan media ponografi serta nilai dan norma-norma yang berlaku dimasyarakat ${ }^{(9)}$.

Perkembangan Anak dan Permasalahannya dalam Buku Ajar I Ilmu Perkembangan Anak Dan Remaja. Jakarta: Sagungseto. Selain itu, faktor yang mempengaruhi perilaku seks bebas pada remaja adalah pengetahuan. Terdapat hubungan yang signifikan antara tingkat pengetahuan yang baik dapat 
memahami perilaku seksual dengan baik pula sedangkan siswa yang memilki tingkat pengetahuan buruk memiliki pemahaman buruk juga tentang perilaku seksual ${ }^{(10)}$.

Hasil dari kegiatan ini dapat berjalan dan dapat di terima dengan baik, dengan ditandai, ketertarikan ibu balita yang mengajukan beberapa pertanyaan dan hasil evaluasi pre test dan post test .

\section{Kesimpulan}

Kegiatan pengadian masyarakat ini "Penyuluhan Remaja sehat, Reproduksi Sehat" pada anak sekolah yang dilaksanakan di Posyandu Remaja Pashmina Kelurahan Jenggot Kota Pekalongan dapat berjalan dengan lancar dan diterima dengan baik. Semua anak remaja antusias mengikuti kegiatan penyuluhan ini. Program penyuluhan semacam ini sangat penting dilanjutkan terutama pada anak usia sekolahdengan cara pendampingan kepada remaja melalui posyandu remaja di wilayah puskesmas jenggot kota pekalongan.

\section{Daftar Pustaka}

[1]. Undang-Undang Nomor 39 Tahun 1999 tentang HAM

[2]. Undang-Undang Nomor 36 Tahun 2009 Tentang Kesehatan

[3]. Depkes RI, Pedoman Penanggulangan Anemia Gizi untuk Remaja Putri dan Wanita Usia Subur (WUS). Jakarta: Ditjen Pembinaan Kesehatan Masyarakat, 2008.

[4] Arisman, Buku Ajar Ilmu Gizi dalam Kehidupan. Jakarta: Penerbit Buku Kedokteran EGC, 2009.
[5] S. Notoatmodjo, Ilmu Kesehatan Masyarakat. Jakarta: Rineka Cipta, 2011.

[6] Styne, D.M. The Regulation Of Pubertas Growth, Horm Res, 2010.

[7] BKKBN, Memahami Dunia Remaja (Seri Informasi KRR, Buku Bacaan Orang Tua), Ed.II. 2002.

[8] Desmita, "Hubungan seks yang dilakukan diluar pernikahan disebut seks bebas (Free sex)," Psikologi Perkembangan, Bandung: PT. Remaja Rosdakarya, 2005.

[9] Soetjiningsih, Perkembangan Anak dan Permasalahannya dalam Buku Ajar I Ilmu Perkembangan Anak Dan Remaja. Jakarta: Sagungseto, 2012.

[10] R. Darmasih, A. S. Noor, G. T. Azizah, "Kajian Perilaku Sex Pranikah Remaja SMA di Surakarta," J. Kesehat., vol. 4, no. 2, pp. 111-119. 